\title{
'First Among Equals': Breaking the Deadlock in Parental and Sibling Funeral Disputes
}

\author{
Heather Conway ${ }^{1}$
}

Published online: 10 July 2018

(C) The Author(s) 2018

\begin{abstract}
Family disputes over a loved one's funeral arrangements are increasingly frequent, with courts intervening if consensus cannot be reached. In many common law jurisdictions, the law favours the executor where the deceased made a will and the highest ranking next-of-kin where the deceased died intestate. But what if two or more people fall within the same kinship tier and have equal rights to determine the deceased's fate-who has the final say? Adopting a uniquely comparative approach which draws the authorities together for the first time, this article analyses the factors devised by judges in Australia and England, and contrasts them with the discrete statutory tests adopted in parts of Canada and the United States. Having evaluated the various approaches, the article proposes its own hybrid legal solution for breaking the deadlock in so-called 'equal kinship disputes'.
\end{abstract}

Keywords Funerals $\cdot$ Families $\cdot$ Disputes $\cdot$ Parents $\cdot$ Siblings $\cdot$ Intestacy

\section{Introduction}

In November 2015, Susanna Levrant and David Freud asked the High Court in London to rule on which of them should decide their dead mother's funeral arrangements. ${ }^{1}$ Mrs Levrant wanted a traditional Church of England ceremony, then burial in a Putney cemetery; Mr Freud insisted on a traditional Jewish funeral followed by interment in consecrated ground in north London. ${ }^{2}$ Three days later, the siblings

\footnotetext{
1 "Siblings in High Court Battle Over Whether Mother Should be Buried in Jewish or Christian Ceremony", The Telegraph (London, 6 November 2015) <http://www.telegraph.co.uk/news/uknews/law-andorder/11980060/Siblings-in-High-court-battle-over-whether-mother-should-be-buried-in-Jewish-or-Chris tian-ceremony.html>.

2 The deceased had been baptised and brought up as a member of the Church of England; her husband (who predeceased her) had been a practising Jew.
}

Heather Conway

h.conway@qub.ac.uk

1 School of Law, Main Site Tower, Queen's University, Belfast BT7 1NN, UK 
compromised: their mother's funeral would be conducted under the neutral auspices of the Master of the Inner Temple Church, before burial in consecrated ground in another Putney cemetery. ${ }^{3}$ In August 2016, the High Court in Northern Ireland faced a similar scenario, when separated parents fought over their adult son who had died from a suspected heart attack, the mother insisting on burial and the father on cremation. ${ }^{4}$ The following day, the court released the deceased's remains to his father, after the mother-reluctant to put the family through a contested hearing-abandoned her claim. ${ }^{5}$ And despite all the media hype, it is important to see the 2016 ruling on whether a 14-year-old girl could be cryogenically preserved in a specialist facility in Michigan for what it actually is: divorced parents fighting over whether or not this should happen. ${ }^{6}$

Disputes within families over a loved one's funeral arrangements occur more often than we might think. They are also increasing as the re-ordering of traditional family networks alongside the emergence of multi-faith, multi-ethnic societies with diverse death rites and customs create new tensions around the fate of the dead. ${ }^{7}$ Where consensus or compromise cannot be reached, an effective legal mechanism is needed to break the deadlock and ensure that bodily disposal takes place, ${ }^{8}$ or that post-cremation ashes are dispersed or otherwise dealt with. ${ }^{9}$ English law, like many common law jurisdictions, contemplates a clear order of entitlement based on succession law principles. ${ }^{10}$ The first point to note is that the deceased's own funeral preferences are not legally binding. ${ }^{11}$ Instead, where the deceased made a will the final say lies with the executor. ${ }^{12}$ For intestate deaths (which occur frequently, both

\footnotetext{
3 “Siblings Compromise Over Mother's Burial", The Times (London, 9 November 2015) <http://www. thetimes.co.uk/tto/news/uk/article4609492.ece>.

4 "Belfast High Court: Parents Ask Judge to Decide Funeral Arrangements", BBC News Online (26 August 2016) <http://www.bbc.co.uk/news/uk-northern-ireland-34064905>. Both parents believed they would be fulfilling their son's wishes.

5 The father had to keep half of the deceased's ashes for the mother-see "Belfast High Court: Father Wins Right to have Son Cremated", BBC News Online (27 August 2016) < http://www.bbc.co.uk/news/ uk-northern-ireland-34076152>.

${ }^{6}$ Re JS (Disposal of Body) [2016] EWHC 2859 (Fam). While the court ruled for the mother, it was the cryonics aspect that attracted headlines—see e.g. "Terminally Ill Teenager with Rare Form of Cancer Wins Landmark High Court Battle to be Cryogenically Frozen", The Independent (London, 18 November 2016) <http://www.independent.co.uk/news/uk/home-news/cryogenically-frozen-teenager-terminally -ill-cancer-a7424036.html>.

7 Conway (2016), ch 4.

8 'Disposal' may seem clinical, but denotes treating human remains in a way which eliminates the public health risk while physically segregating the dead from the living. Burial and cremation remain the two dominant options.

9 Families fighting over ashes is very common. Although the same legal rules apply in determining who has the final say (Robinson v Pinegrove Memorial Park Ltd (1986) 7 BPR 15 097), the fact that ashes can be scattered, retained, and dealt with in different ways raises a host of issues-see the respective discussions in Leeburn v Derndorfer [2004] VSC 172 and Doherty v Doherty [2007] Qd R 259.

${ }^{10}$ Conway (2016), pp 61-67.

11 Williams $v$ Williams (1882) 20 Ch D 659.

12 Williams $v$ Williams (1882) 20 Ch D 659 and Grandison v Nembhard [1989] 4 BMLR 140.
} 
here and elsewhere), ${ }^{13}$ the decision lies with the highest ranking next-of-kin as defined by the list of potential estate administrators. Much depends on the relevant intestacy framework, but in most instances a surviving spouse or civil partner takes priority, followed by the deceased's children, then parents, then sisters or brothers. ${ }^{14}$ Delineating rights by a descending order of relational ties means, for example, that courts will favour a husband or wife over the deceased's parents or siblings where the two sides clash over funeral arrangements. ${ }^{15}$ But if, as in the opening examples, the disagreement involves persons within the same kinship tier with equal rights to determine the deceased's fate, these rules offer no solution and an alternative has to be found. ${ }^{16}$

Ranking competing claims when the protagonists have the same legal and familial affiliations to the deceased raises all sorts of issues which have been largely overlooked in academic literature. ${ }^{17}$ This is surprising - not just because of a spate of high-profile contests, but given the significant volume of case law from courts in England and Australia in particular. Meanwhile, other jurisdictions have developed their own legislative solutions, which also tend to be ignored or looked at in isolation. Adopting a uniquely comparative approach, this article draws the disparate strands of jurisprudence together for the first time, and examines the fundamentally different ways in which specific common law jurisdictions with similar socio-cultural attitudes towards death resolve so-called 'equal kinship disputes'.

Initially, the focus is on England and Australia where the problems caused by the lack of a clear legal rule have been exposed repeatedly. Here, judges have had to proceed from first principles, creating an improvised jurisprudence. The article goes on to examine legislative provisions in parts of Canada and the United States of America which apply specific rankings; these range from favouring the eldest protagonist at one extreme, to more emotive notions of who was closest to the deceased at the other. Focusing on these frameworks, and drawing on aspects of succession and family law, as well as the fields of 'death studies' and law and emotion, the article questions whether such subjective value-judgments are a good idea, or whether an objective ranking is better for all concerned. It concludes by proposing its own hybrid solution, creating a distinctive statutory mechanism for resolving equal kinship disputes.

\footnotetext{
13 The English Law Commission estimates that $40 \%$ of adults in England and Wales have not made a will (Law Commission (2017), p 5), though the figure could be high as two-thirds.

${ }^{14}$ In England and Wales, see s 46 of the Administration of Estates Act 1925 (as amended).

${ }^{15}$ See e.g. Saleh v Reichert (1993) 104 DLR (4th) 384 (deceased's husband outranked her father) and Threlfall $v$ Threlfall [2009] VSC 283 (coroner erred in releasing the deceased's body to his brother instead of his widow).

${ }^{16}$ Similar issues arise where joint executors under a will disagree over funeral arrangements, though this occurs less frequently. For an isolated example see Leeburn v Derndorfer [2004] VSC 172 where siblings who were joint executors under their dead father's will clashed over his ashes.

${ }^{17}$ There is a short comment Freckelton (2009) and the matter is mentioned briefly in Conway (2016), pp 95-97.
} 


\section{Legal Deficits and Limitations}

Equal kinship disputes occur in two classic situations: siblings fighting over a dead parent, ${ }^{18}$ and parents quarrelling over a dead child after their own relationship has broken down. Siblings fighting over another dead sibling is also a possibility, where the brother or sister died without legally closer kin (in other words, leaving no spouse/civil partner, children or surviving parents). Yet, the first two scenarios are much more common, and are some of the most bitter and contested conflicts. Divorced or separated parents will often embark on one final and decisive custody dispute $^{19}$ following the death of a child; this is often an infant or minor child, ${ }^{20}$ but can also be an adult son or daughter who dies without without leaving a spouse or civil partner, or children of their own. Sibling strife is just as commonplace, not just within reconstituted families where the deceased's children from different relationships vie for priority, but intact families where (old) sibling rivalries are triggered by parental loss and the resultant emotional maelstrom. ${ }^{21}$

Such unresolved family tensions make consensus difficult to achieve, forcing courts to choose a particular parent or sibling and end the impasse. ${ }^{22}$ This is not a task that judges relish. First, decisions must be reached within a compressed timeframe, and not just because decaying corpses pose a public health risk. ${ }^{23}$ The core societal value of respect for the dead mandates a quick resolution: storing corpses or ashes while discordant relatives litigate their fate in protracted legal disputes offends some basic sense of social mores. ${ }^{24}$ Secondly, equal kinship disputes (for the most part) lack a discrete legal solution. While these might seem like a family law issue, funeral disputes are resolved by succession law rules; yet, these are ineffective here, since intestacy laws do not distinguish between individuals within the same

\footnotetext{
${ }^{18}$ In most cases, this will be the deceased's biological or adoptive children, since step-children have lesser rights. The position will be different in Scotland when s 65 of the Burial and Cremation Act (Scotland) 2016 takes effect (deceased's adult child(ren) can decide his/her funeral arrangements; stepchild to be treated as a child of the deceased).

19 While English family law no longer uses the term 'custody' (s 8 of the Children Act 1989 deals with 'residence' and 'contact' under "child arrangement orders"), this particular terminology will be used for convenience throughout.

${ }^{20}$ Intestacy-based principles may seem irrelevant, because a child usually has no estate to administer. However, both parents would be entitled to a grant of administration if there was one (in England and Wales, see the Non-Contentious Probate Rules 1987, SI 1987/2024, r 22(1)(c)), creating joint rights to decide their child's funeral arrangements—Scotching v Birch [2008] EWHC 844 (Ch).

21 See e.g. Milevsky (2013).

22 A negotiated solution is always preferable to litigating to the finish, and funeral disputes are no exception. Mediation has a role to play (see Josias (2004) and Oldfield (2014)), but does not always succeed. Time constraints (see immediately below) and damaged family relationships act as barriers, though there is also the fact that the overriding aim here is to ensure that corpses or ashes are dealt with (not capacity building processes which foster functional relationships within families-the 'holy grail' of family law mediation).

23 Though this danger is more apparent than real, since there is no scientific (or legal) barrier to refrigerating corpses, to facilitate a full hearing and subsequent judicial deliberation. Of course, ashes pose no threat to public health.

24 Sentiments reflected in some of the judgments on family funeral disputes - see Conway and Stannard (2011), pp 886-891.
} 
relational class. Ancillary rules for administering estates if joint personal representatives disagree offer no comparable solutions ${ }^{25}$ and, unlike inheritance contests where courts can appease warring relatives by dividing assets, a similar option is not available unless the deceased has been cremated and splitting the ashes is an acceptable compromise. ${ }^{26}$ In England and Wales, limited assistance can be found in s 116 of the Senior Courts Act 1981 which allows the High Court to appoint a different administrator (or executor) if "special circumstances" make it "necessary or expedient" to do so. ${ }^{27}$ Yet, while applicable in equal kinship disputes, ${ }^{28}$ the legislation is silent on what constitutes 'special circumstances' for substituting one individual for the other(s), leaving judges to draw their own conclusions on the facts. And recourse to the court's inherent jurisdiction, as a procedural alternative, ${ }^{29}$ presents exactly the same problem.

In short, when faced with equal kinship disputes, English courts have had to develop specific ways of prioritising one parent or sibling over the other(s). This experience is not unique, with courts in Australia facing the same problem (again, there is no legislative guidance, beyond the basic intestacy rules). ${ }^{30} \mathrm{~A}$ distinct body of case law has emerged in both jurisdictions; detailed analysis reveals a mixture of commonalities and contradictions, as the following sections show.

\section{Common Law Tie-Breakers: England and Australia}

While both the factual narratives and outcomes differ (as we might expect), several broad themes have emerged from the case law.

\footnotetext{
${ }^{25}$ In England and Wales, r 27 of the Non-Contentious Probate Rules 1987, SI 1987/2024 favours a person of full age in preference to a guardian of a minor, and a living person over the personal representative of a deceased person ( $\mathrm{r} 27(5)$ ), but otherwise leaves the matter to the court ( $\mathrm{rr} 27(6)-(8))$. However, the usual practice is to select the individual who is best placed to administer the estate (Re Loveday [1900] P 154), or with the largest interest in it (Dampier v Colson (1812) 2 Phill 54).

${ }^{26}$ This must be acceptable to all of the equally ranked kin, and is not an option where one party objects-see Fessi $v$ Whitmore [1999] 1 FLR 767 (discussed at nn 42-44 and accompanying text). Of course, there is no prospect of carving up a corpse in this manner-described as "unthinkable" by Byrne $\mathrm{J}$ in Leeburn v Derndorfer [2004] VSC 172 at [31]. Public health and the core value of respect for the dead would prevail, even if the protagonists favoured such a macabre compromise.

${ }^{27} 1981$ Act, s 116(1). Although more commonly concerned with estate management, disposal of the dead also falls within its ambit—see e.g. Buchanan v Milton [1999] 2 FLR 844 and Burrows v HM Coroner for Preston [2008] EWHC 1387 (Admin).

28 According to Peter Jackson J in Re JS (Disposal of Body) [2016] EWHC 2859 (Fam), though in Anstey $v$ Mundle [2016] EWHC 1073 (Ch) (decided some nine months earlier) Klein J was less convinced that s 116 was engaged in a sibling dispute over parental remains.

${ }^{29}$ Preferred in both Hartshorne v Gardner [2008] EWHC B3 (Ch) and Anstey v Mundle [2016] EWHC $1073(\mathrm{Ch})$, and the procedural mechanism used in most of the Australian cases cited in the following section.

${ }^{30}$ The same applies in Northern Ireland (as the opening example illustrates), and in New Zealand and the various Canadian provinces with the exception of those noted in the section entitled 'Statutory Rules for Breaking the Deadlock' below though the volume of reported case law from these jurisdictions is lower.
} 


\section{Expediting the Funeral}

Where the body has yet to be buried or cremated, ensuring that this occurs as quickly as possible is crucial for reasons already identified. Expediting the funeral was singled out as "the most important consideration" in the English case of Hartshorne $v$ Gardner $^{31}$ — sentiments repeated almost a decade later in Anstey v Mundle. ${ }^{32}$ This particular factor proved decisive in two Australian cases.

In Calma $v$ Sesar, ${ }^{33}$ separated parents fought over their adult son. The mother had arranged for a Catholic burial in Darwin; the father preferred the family plot near Port Hedland, Western Australia. Martin J emphasised that lifetime quality of parenting was irrelevant, and refused to be influenced by religious and cultural factors or other "imponderables" 34 despite both parents and the deceased being of Aboriginal descent. Stressing the need for the matter to be resolved "in a practical way... [and] without unreasonable delay", ${ }^{35}$ Martin J gave custody of the body to the mother as it was already in Darwin (albeit with a funeral director instructed by the father-this was irrelevant, as was the fact that the mother had already applied for a grant of administration over her son's estate). There was "no good reason in law"36 for preferring Port Hedland, some $2000 \mathrm{~km}$ away.

Substantively similar issues arose a decade later when divorced spouses clashed in Burrows $v$ Cramley, ${ }^{37}$ the mother wanting to bury her 17-year-old son in Perth and the father favouring Sydney. Pullin J acknowledged that mother and son had ceased contact for several months before his death, and that the father (as custodial parent) almost certainly "provided the greater care" 38 for his son. Once again, these were extraneous considerations:

[E]vidence about where the deceased lived and why is relevant, but...detailed evidence about who, out of two parents, provided the most [sic.] support and comfort, is not relevant to the decision I have to make. ${ }^{39}$

Drawing on comments in Smith v Tamworth City Council ${ }^{40}$ that "the practicalities of burial without unreasonable delay" were paramount, Pullin J ruled for the mother. The son had died in Western Australia and burial in Perth would be more practical; the father was currently in Perth, and was better placed financially to visit his son's

\footnotetext{
31 [2008] EWHC B3 (Ch) at [9].

32 [2016] EWHC $1073(\mathrm{Ch})$. Both cases are mentioned further in the discussion below.

33 (1992) 106 FLR 446.

34 (1992) 106 FLR 446 at 452.

35 (1992) 106 FLR 446 at 452.

36 (1992) 106 FLR 446 at 452. See also Joseph v Dunne [2007] WASC 238 (eight-year-old's body released to his father, partly because he had arranged a funeral for the following day).

37 [2002] WASC 47.

38 [2002] WASC 47 at [32].

39 [2002] WASC 47 at [32].

40 (1997) 41 NSWLR 680 at 694 (Young J).
} 
grave. His offer to pay for the mother to visit the grave regularly did not sway the final decision. ${ }^{41}$

\section{Detachment from the Place of Death}

In sudden or violent deaths, English courts have occasionally favoured the person who wants the deceased laid to rest, away from the scene of the tragedy. A good illustration is Fessi $v$ Whitmore ${ }^{42}$ in which a divorced couple fought over their 12-year-old son's ashes. The boy lived with his father in Nuneaton (where the entire family had always lived), until a few weeks before his death when father and son had moved to Wales, and the boy had been buried in sand while playing on a beach. The mother wanted to scatter the ashes in Nuneaton; the father wanted to inter them near his new home. Splitting the ashes was "wholly inappropriate" 43 because the father objected, forcing the judge to choose between the parties. Circumstances favoured the mother: the father's preference would cause "enormous distress" 44 to the family (being so close to the scene of the accident), whereas Nuneaton was a more fitting focal point for everyone. Like Burrows $v$ Cramley, ${ }^{45}$ the fact that the father was the custodial parent was irrelevant.

In Scotching $v$ Birch ${ }^{46}$ the dispute was also between the separated parents of a dead 5-year-old boy. The mother had killed the child and attempted suicide afterwards, following a court hearing to discuss contact arrangements with his father. She had pleaded guilty to unlawful killing, but was in prison awaiting trial for murder, and wanted to bury her son in the graveyard of the church where her other three children were christened; this was near the family home and scene of death. The father did not want his son interred there, preferring a grave close to where the father lived. Invoking the forfeiture rule to deny the mother's notional right as administrator of her son's estate-public policy decrees that someone who is criminally responsible for another's death cannot inherit from them-the court ruled for the father. This was despite the father having had virtually no contact with his son for several years, and the deceased's half-siblings siding with their mother (all three were minors, but wanted to be able to visit their brother's grave and maintain strong sibling attachments).

\section{Affective Place Connections}

Another way of analysing Fessi $v$ Whitmore Wh $^{47}$ is that the deceased's emotional and geographical ties to a particular place are important-hence the court's decision to give the ashes to his mother, to be scattered where the family had lived together

\footnotetext{
41 In Joseph v Dunne [2007] WASC 238 (see n 36), the fact that the mother could probably not afford visits to her son's grave was relevant but not persuasive.

42 [1999] 1 FLR 767.

43 [1997] 1 FLR 767 at 770.

44 [1997] 1 FLR 767 at 770.

45 [2002] WASC 47.

46 [2008] EWHC 844 (Ch).

47 [1999] 1 FLR 767.
} 
in happier times. ${ }^{48}$ Substantively similar reasoning can be seen in Hartshorne $v$ Gardner, ${ }^{49}$ when divorced parents fought over their 44-year-old son's remains (the mother favoured cremation and interment of the ashes in Worcester where she lived; the father wanted burial some 40 miles away in Kington). In listing relevant factors, the deputy judge included "the location with which the deceased was most closely connected". ${ }^{50}$ On the facts, this was Kington: the deceased had lived in the town for the past 8 years and his fiancée, brother and father all wanted him to be buried there. The fact that the mother (who was in her 70s, and did not drive) would find it difficult to visit her son's grave was a "weighty factor", 51 but not decisive.

\section{Lifetime Relationships with the Deceased}

Despite the emphasis on external factors, Australian courts have occasionally selected the person with the closest emotional tie to the deceased. In Keller $v$ Kel$l e r,{ }^{52}$ the deceased's daughter could cremate her remains (fulfilling what were apparently her mother's wishes), despite objections from the deceased's son who wanted burial in accordance with traditional Jewish law and custom. Hargrave J described the daughter as "the child in whom the deceased reposed her principal trust and confidence", 53 highlighting the deceased's failure to tell her son about her cancer diagnosis and the fact that she had previously sought a restraining order against him.

In $A B v C D^{54}$ separated parents disagreed over the funeral arrangements for their infant son. The child had lived with his mother who wanted to bury him in a cemetery close to where she was living with her new fiancé; the father (who had had little contact with his son) wanted somewhere closer to where the father lived. Harrison $\mathrm{J}$ refused to be swayed by the arguments around the two different burial sites; in the judge's opinion, the importance of visiting their son's grave had "been elevated to a level that [would] recede with the passing of the years". ${ }^{55}$ The key factor was the child's relationship with his mother, which tipped the judicial scales her favour:

[O]ne factor appears to dominate all others. The plaintiff has had the primary care and responsibility for her son since birth... [The child] had a large number of people in his life who loved him, but his relationship with his mother was necessarily unique.

Closer to home, the decision in Re JS (Disposal of Body $)^{56}$ is underpinned by a similar rationale. The terminally-ill teenager who wanted to be cryogenically frozen had

\footnotetext{
48 This resonates with notions of place attachment, and affective connections to a particular location or physical landscape based on symbolic meanings or emotional ties-Altman and Low (1992).

49 [2008] EWHC B3 (Ch).

50 [2008] EWHC B3 (Ch) at [9].

51 [2008] EWHC B3 (Ch) at [24].

52 [2007] VSC 118.

53 [2007] VSC 118 at [18].

54 [2007] NSWSC 1474.

55 [2007] NSWSC 1474 at [62]. This is an unusual statement, given what are typically strong emotional attachments to a loved one's grave-Petersson (2010).

56 [2016] EWHC 2859 (Fam).
} 
lived with her mother, was refusing all contact with her father, and had not seen him since 2008. The close maternal relationship, combined with the "nature of the family breakdown and of JS's wishes" $" 57$ were special circumstances for making the mother sole estate administrator under s 116 of the Senior Courts Act 1981-and allowing her to trigger the cryonics process.

\section{The Deceased's Wishes}

The deceased's own funeral preferences (if known) can act as a reference point for resolving equal kinship disputes ${ }^{58}$ despite not being legally binding. These were an important part of the factual matrix in $R e J S$, even if the judge categorised them as "relevant, perhaps highly so, but...not determinative". ${ }^{59}$ However, the deceased's expressed wish to be buried in his native Jamaica, next to his mother, swayed the outcome in Anstey $v$ Mundle ${ }^{60}$ when two of his three daughters insisted on burial in England and the other (supported by the deceased's niece) favoured repatriation. According to Klein J, this was a "particularly weighty factor", 61 and the deceased's extended family (who he was very close to) all supported a Jamaican burial.

\section{Pragmatism Over Principle?}

While some trends have emerged, most of these decisions seem to be based on pragmatism rather than legal principle. Analysing the case law does not reveal a cohesive set of rules, because the various judicial rationales have often been applied inconsistently. For example, courts might favour a custodial parent in disputes involving infants or minors but this practice is by no means universal, ${ }^{62}$ and diminished levels of contact between parent and child are not always determinative. ${ }^{63}$ Likewise, the location of the gravesite and ease of access for future visiting may be more relevant in some cases than in others, ${ }^{64}$ while judges have also been swayed by the organisation and timing of conflicting funeral arrangements, ${ }^{65}$ as well as connections (both

\footnotetext{
57 [2016] EWHC (Fam) 2859 at [54].

58 Identified as another relevant consideration in Hartshorne v Gardner [2008] EWHC B3 (Ch).

59 [2016] EWHC 2859 (Fam) at [48].

60 [2016] EWHC 1073 (Ch).

61 [2016] EWHC 1073 (Ch) at [45].

62 Contrast $A B v C D$ [2007] NSWSC 1474 and Joseph $v$ Dunne [2007] WASC 238 with Burrows v Cramley [2002] WASC 47 and Fessi v Whitmore [1999] 1 FLR 767.

63 Compare $A B v C D$ [2007] NSWSC 1474 with Scotching v Birch [2008] EWHC 844 (Ch).

64 Contrast Burrows v Cramley [2002] WASC 47 with both Joseph v Dunne [2007] WASC 238 and Hartshorne v Gardner [2008] EWHC B3 (Ch), though the geographical distance was greatest in the first case.

65 See Calma v Sesar (1992) 106 FLR 446, Burrows v Cramley [2002] WASC 47 and Joseph v Dunne [2007] WASC 238.
} 
bad and good) to a proposed burial place. ${ }^{66}$ The range of factors taken into account in each case and the weight attached to them also varies significantly. On the one hand, this allows for a uniquely responsive solution-one which recognises that all funeral disputes are underpinned by their own distinctive family dynamics and practicalities. Yet there are drawbacks.

Flexibility and unpredictability are natural bedfellows, and can encourage litigation between feuding parents or siblings who believe they have nothing to lose in applying to court and raising peripheral issues. Meanwhile, other seemingly important factors tend to be downplayed. Religious and cultural imperatives are an obvious example, despite featuring heavily in some of the cases discussed here: the judge pointedly ignored them in Calma $v$ Sesar, ${ }^{67}$ and the issue was side-stepped in Keller $v$ Keller $^{68}$ when the court focused on which child was closer to the deceased. This is surprising, given the way in which religious and cultural values shape specific death rites, and their prominence in other bodily disposal cases: though not determinative in the legal arena, such values are increasingly influential when central to the factual narrative. ${ }^{69}$ Both Calma and Keller contrast sharply, however, with the recent case of Abraham v Magistrate Stone, Deputy State Coroner ${ }^{70}$ where the judge ruled for the father in a parental dispute over a teenage boy's funeral arrangements. Maori culture played a prominent role here, with the mother arguing (and the court accepting) that burial in ancestral lands was preferable to cremation. However, contemporary Maori practices also recognised cremation, and the need for consensus or compromise in reaching a decision. The father could cremate his son's body and divide the ashes with the mother, allowing both to arrange culturally appropriate burial services-a compromise supported by other family members.

Despite the case law disparities, two things stand out. The first is an apparent need to resolve such cases as quickly as possible, and this compressed timeframe is repeatedly mentioned, even in disputes involving ashes. ${ }^{71}$ The second is a reluctance

\footnotetext{
66 See Fessi v Whitmore [1999] 1 FLR 767, Scotching v Birch [2008] EWHC 844 (Ch) and Hartshorne v Gardner [2008] EWHC B3 (Ch). The various factors can be taken collectively, or in isolation, depending on the facts. In Johnson v George [2018] QSC 140, which involved a funeral dispute between eight of the deceased's nine adult children, the court ruled for the applicant son and several of his siblings because the deceased had asked to be buried at the location they were proposing and had strong connections with that place (one of the deceased's sons was buried there); burial there would not be expensive or logistically inconvenient. However, Aboriginal cultural and spiritual beliefs were also important in this case-see n 70 .

67 (1992) 106 FLR 446.

68 [2007] VSC 118.

69 Though not equal kinship disputes, other Australian cases post-Calma (mostly involving indigenous peoples) were more receptive to religious and cultural influences-see Conway (2016), pp 104-107. For more recent illustrations, see Darcy and Duckett [2016] NSWSC 1756, Bertani v Bertani [2017] WASC 78, and the decision of the New Zealand Supreme Court in Takamore v Clarke [2012] NZSC 166.

70 [2017] NSWSC 1684. See also Johnson v George [2018] QSC 140 (discussed at n 66) where Aboriginal culture and traditions were a key influence and, in ruling for the applicant son over his respondent sister (who was also supported by several other siblings), North J acknowledged that, when it came to the funeral of an Aboriginal man, it was customary for a son of the deceased to control the funeral arrangements.

71 See e.g. Leeburn v Derndorfer [2004] VSC 172 and Keller v Keller [2007] VSC 118.
} 
to decide equal kinship disputes on the basis of close personal ties to the deceased. ${ }^{72}$ Isolated examples exist as mentioned above, and the outcome in each seems intuitively correct. Yet, judges have gone to great lengths to ensure that decisions should not be viewed as a qualitative assessment of ante-mortem relationships between the living and the deceased-especially in parental disputes over a dead child. For example, Harrison $\mathrm{J}$ in $A B v C D^{73}$ emphasised that the court's ruling was "not, and should not appear to be, a prize for who was the better parent", sentiments echoed by the deputy judge in Hartshorne $v$ Gardner ${ }^{74}$ :

[A] decision between the earnest wishes of two grieving parents requires the wisdom of Solomon, which I do not profess to have. Any decision will be hard to take for the losing party, but I must make it absolutely clear at the outset that the decision I am making involves no criticism of either parent.

For the most part, English and Australian courts avoid delving into family histories and conflicting narratives, preferring to separate equal claims using extrinsic factors which facilitate a swift resolution. This contrasts sharply with some of the statutory frameworks adopted elsewhere, as the following section illustrates.

\section{Statutory Rules for Breaking the Deadlock: Parts of Canada and the United States}

Other common law jurisdictions have specific legislation for resolving funeral disputes. Most favour a descending order of entitlement, which prioritises the personal representative or an individual who the deceased nominated, in a will or other written directive, to take charge of the funeral arrangements; this is followed by a surviving spouse (which can include a de facto or cohabiting partner, depending on the statute), then children and other specified relatives. ${ }^{75}$ Some of these statutes also contain specific rules for resolving equal kinship disputes, ranging from seemingly arbitrary markers on one extreme to more subjective evaluations on the other.

\section{Nominating the Eldest: Selected Canadian Provinces}

In British Columbia, s 5(3) of the Cremation, Interment and Funeral Services Act 2004 states that, in a dispute over the disposition of human remains between persons of equal rank, the order of priority should be determined by agreement or (failing

\footnotetext{
72 This resonates with the modern approach in family law, where judges are reluctant to declare who is a good mother or father in child residence or custody disputes-see nn 111-112 and accompanying text. 73 [2007] NSWSC 1474 at [66].

74 [2008] EWHC B3 (Ch) at [2]-[3].

75 In the Canadian context, see s 5(1) of the Cremation, Interment and Funeral Services Act 2004 (British Columbia) and s 91(1) of the Funeral Services Act 1999 (Saskatchewan). Numerous examples exist in the US - see the statutory provisions noted immediately below, as well as WASH. REV. CODE $\S$ 68.50.160 (Washington), COLO. REV. STAT. $§ ~ 12-34-204$ (Colorado) and TEX. HEALTH AND SAFETY CODE ANN. $§ 711.002$ (Texas).
} 
that) in order of age descending from the eldest. ${ }^{76}$ Similar provisions are in force in Alberta ${ }^{77}$ and Saskatchewan. ${ }^{78}$ Under each statute, feuding siblings must be adults to have decision-making powers, though (perhaps unsurprisingly) no such condition is attached to parents of the deceased. ${ }^{79}$ However, the key factor is that funeral disputes between parents or adult siblings are determined solely on the basis of age - and this approach appears unique to these three provinces. ${ }^{80}$

\section{From Majority Preference to Closest Relationship: Selected US States}

Unlike other common law jurisdictions, funeral instructions have frequently been upheld in the United States of America. ${ }^{81}$ A number of states now have "mortal remains statutes' which apply a default listing of authorised decision-makers only if the deceased's wishes are unknown, unclear or contested ${ }^{82}$; some also contain specific rules for settling equal kinship disputes.

\section{Majority Preference: New Jersey}

In the state of New Jersey, the emphasis is on 'majority preference'. When contesting the fate of parental remains, N.J. STAT. ANN. 45:27-22 favours "a majority of the surviving adult children of the deceased" 83 ; in sibling disputes surrounding a brother or sister who died without legally closer kin, the final decision lies with "a majority

\footnotetext{
${ }^{76}$ However, this is subject to the deceased's expressed wishes, set out in a will or funeral services contract-2004 Act, s 6.

77 Under s 36(3) of the General Regulation (Funeral Services Act) Alta Reg 226/98 ("the order of priority begins with the eldest person... and descends in order of age") and see also ss 11(2)-(3) of the General Regulation (Cemeteries Act) Alta Reg 249/1998.

78 Section 91(2)(b) of the Funeral Services Act 1999 (Saskatchewan) designates the "elder or eldest of the persons in the same category" as the "authorized decision-maker".

79 Perhaps the respective legislatures simply assumed that both parents would usually be adults (the number of situations in which two minor parents - or one minor and one adult-have a child who dies and a contested funeral would presumably be very small), or were unwilling to deny underage parents a say in their child's funeral arrangements.

${ }^{80}$ Though this used to be the approach in the District of Columbia-see n 87. The US Defense Department also operated a blanket policy of giving a slain soldier's remains to the older of their two surviving parents, in the event of a conflict between them. As a result, the remains of Army Staff Sgt Jason Hendrix, who died in Iraq in 2005, were given to his 48-year-old father instead of his 45-year-old mother"Judge Backs Father on Burial of Son Killed in Iraq", Los Angeles Times, 2 November 2005.

81 Though state dependent, the common law traditionally viewed the wishes of the deceased as paramount-see Conway (2016), pp 130-134.

82 The four jurisdictions discussed here are New Jersey, District of Columbia, Minnesota and Pennsylvania, with funeral instructions being prioritised respectively in N.J. STAT. ANN. 45:27-22(a); D.C. CODE § 3-413(a); MINN. STAT. § 149A.80, subd 1; and 20 PA. CONST. STAT. ANN. § 305(d)(2). As a result, custody of the deceased's remains will be given either to the nominated individual in the deceased's will, or to the highest ranking relative who will carry out the deceased's instructions.

83 N.J. STAT. ANN. 45:27-22(a)(2).
} 
of the [surviving] brothers and sisters". ${ }^{84}$ The same legislation simply states that a surviving parent or parents control the funeral arrangements for a deceased child. ${ }^{85}$

In contests between children and in those involving siblings, the age distinction may or may not be intentional but has obvious ramifications: the deceased's minor children have no effective input (the legislation refers to "adult" children only), yet the same restriction does not apply to the sibling category. As a hypothetical example, a 15-year-old son has no legal say in a parent's funeral arrangements where his adult siblings are fighting over this; the same teenager would, however, be able to influence the outcome in contests involving a dead sibling.

\section{Subjective Assessments: District of Columbia, Minnesota and Pennsylvania}

Legislative provisions in several other US states contemplate a more subjective assessment. In the District of Columbia, D.C. CODE § 3-413 imposes a specific kinship ranking, and in the case of equal entitlements, favours "the majority of the competent adult children" of the deceased with the same rule being applied to adult siblings as "surviving competent adult[s]...in the next degree of kindred". 86 In parental disputes, the legislation simply favours the "surviving competent parent or parents of the deceased". ${ }^{87}$ Where these fail to produce a decision, D.C. CODE $\S$ 3-413.01 states that conflicts over the deceased's remains should be determined by the following factors:

(1) The reasonableness, practicality and resources available for payment of the proposed arrangements and final disposition;

(2) The degree of the personal relationship between the decedent and each of the persons in the same degree of relationship to the decedent;

(3) The expressed wishes and directions of the decedent and the extent to which the decedent has provided resources for the purpose of carrying out those wishes or directions; and

(4) The degree to which the arrangements and final disposition will allow for participation by all who wish to pay respect to the decedent to participate.

Effectively the same legal framework exists in Minnesota under MINN. STAT. $\S$ 149A.80, with the legislative emphasis (once again) on the "degree of the personal

\footnotetext{
84 N.J. STAT. ANN. 45:27-22(a)(4).

85 N.J. STAT. ANN. 45:27-22(a)(3). Again, in the case of an adult child, this assumes the absence of higher ranking kin, such as a surviving spouse or a civil union or domestic partner.

${ }^{86}$ However, in both instances, decision-making powers will be given to less than a majority where they have "used reasonable efforts to notify" all other surviving competent adult children and kin of the arrangements, and are unaware of any opposition-D.C. CODE § 3-413.

87 Previous laws favoured the oldest adult in each class, except for parental disputes where the father was preferred to the mother. However, the latter edict was declared unconstitutional on grounds of gender discrimination-Parker v Hornton's Funeral Service Inc 200 F.R.D. 1 (D.D.C. 2001) (father initially preferred to mother, who was 3 years older).
} 
relationship" between each individual and the deceased in equal kinship disputes. ${ }^{88}$ Both statutes are silent on the meaning of this specific term, and what courts should look for. However, it seems to suggest emotional bonds and ongoing interactions, implicitly favouring the person who had the closest lifetime connection with the deceased.

Finally, in Pennsylvania, there is a notable shift in emphasis. Here, the majority view is irrelevant and the relationship between the deceased and each individual is the sole, decisive factor. According to 20 PA. CONST. STAT. ANN. $§ 305(d)(2)$ :

If two or more persons with equal standing as next-of-kin disagree on disposition of the decedent's remains, the authority to dispose shall be determined by the court, with preference given to the person who had the closest relationship with the deceased. ${ }^{89}$

Again, the legislation does not define what is meant by 'closest relationship' and its inherent qualities, leaving this interpretative task to the courts. For example, the judge in Estate of N.P. ${ }^{90}$ examined a range of factors including the number of telephone conversations between the deceased and each protagonist. In In re Estate of Weiss $^{91}$ the contest was between the deceased's adult sons, one of whom favoured cremation in accordance with his mother's wishes while the other insisted on burial. Having acknowledged the "painful and delicate issue" 92 before the court, Herron J offered the following reassurance:

There is no doubt...that both [sons]...deeply cared for and loved their mother. Determining which of [them]...had the "closest" relationship for the purposes of section 305 in no way reflects on their love or seeks to judge it. ${ }^{93}$

Ruling for the first son, Herron J listed certain "objective criteria"94 as evidence that the deceased was closer to him-including the fact that the mother had given this son power of attorney over her lifetime health and welfare, as well as joint power of attorney for her financial affairs. ${ }^{95}$

\footnotetext{
88 MINN. STAT. $§ 149$ A.80, subd 5. Again, this assumes that a majority view cannot be reached.

89 The same statute also allows for allegations of "enduring estrangement" between the deceased and next-of-kin who would otherwise have decision-making authority, defined as a "physical and emotional separation from the deceased" which existed for a period of time "demonstrat[ing] an absence of due affection, trust and regard for the deceased"-see respectively, 20 PA. CONST. STAT. ANN. § 305(b)(c) and $\S 305(\mathrm{e})$.

9022 Fid. Rep. 2d 473 (Berks Cty. O.C. 2002).

912009 Philia. Ct.Com. Pl. LEXIS 236 (Oct. 1, 2009) (appeal dismissed without opinion at $2011 \mathrm{~Pa}$. Super. LEXIS 1675 (Pa. Super. Ct., Mar. 24, 2011)).

922009 Philia. Ct.Com. Pl. LEXIS 236 (Oct. 1, 2009) at [*1].

932009 Philia. Ct.Com. Pl. LEXIS 236 (Oct. 1, 2009) at [*3].

942009 Philia. Ct.Com. Pl. LEXIS 236 (Oct. 1, 2009) at [*3].

95 Pennsylvania courts have been factoring emotional closeness (and models of good behaviour) into funeral disputes, long before the current statutory regime. In Boyd v Gwyn 6 Pa. D. \& C. 275 (1925), a dispute between a sister and two brothers over their father's funeral, the court favoured the sister-a dutiful and loving child, who intended to bury her father in a family grave in his boyhood home of Nashville. Her two brothers had had little contact with their father for almost 20 years and, driven by their animosity towards him, wanted burial in Philadelphia where the deceased had no family or contacts.
} 


\section{The 'Right' Result or the Quickest One?}

These statutory frameworks oscillate between two extremes when adjudicating equal claims: that of a blunt ranking according to age or majority preference, contrasted with emotionally intuitive notions of who had the best personal relationship with the deceased. However, each generates its own problems.

With age and majority preference, the emphasis is on finding a quick and decisive solution to a complex and difficult issue-the legislative equivalent of cutting the Gordian knot. Both are effectively rules of convenience: they allow decisions to be made in scenarios where one has to be made, so that the dead can be laid be rest. Judges can dispense with individual cases (should the dispute even get this far), ${ }^{96}$ without having to probe family hostilities or make value-judgments about prior affiliations between the living and the dead.

Looking at the individual markers, an outcome based on majority preference (in essence, a form of 'majority rule') is superficially attractive. Adopting one of the core values of a democratic society resonates with notions of fairness, and ensures that some measure of consensus permeates the decision-making process. The embedded element of certainty of outcome also makes it a useful mechanism for resolving contests between three or more of the deceased's siblings or children. ${ }^{97}$ Yet, there are drawbacks. The most obvious is reaching an attainable majority. Since this particular tie-breaker requires a numerical advantage on one side, ${ }^{98}$ it does not work in parental disputes over a dead child ${ }^{99}$ or where equal numbers of siblings are pitched against each other. The fact that the majority can legitimately ignore the minority view is also problematic (the so-called 'tyranny of the majority'), and can fuel underlying tensions. Take three siblings, one of whom cared for their elderly mother and handled all her personal affairs, while the others were occasional visitors; here, the care-giving sibling would be overruled if the other two insisted on specific funeral arrangements, because the nuances of family life are irrelevant. Finally, there is the eligibility issue. Each statutory regime only recognises the

\footnotetext{
96 Age-based rankings would (presumably) deter litigation because the eldest would automatically succeed. For an isolated example in Saskatchewan, see Saunders v Saskatoon Funeral Home Company Ltd 2016 SKQB 217 (post-cremation ashes excluded on the wording of the particular statute; father not entitled to his daughter's ashes by virtue of being older than the mother).

97 For example, the court's task in Anstey v Mundle [2016] EWHC 1073 (Ch) (see nn 60-61 and accompanying text) would have been much easier-though the outcome very different-since two of the three siblings wanted their father buried in England.

98 Assuming there are at least three claimants of equal standing, two or more must agree and be able to tip the balance in one side's favour; for example, two versus two on each side would still result in deadlock and there is no concept of a 'casting vote'.

99 While science has pioneered 'three parent children' (see Hamzelou (2016)) this is not reflected in current English law where parental status is still based on two individuals. However, there may be situations in which more than two people have parental authority for a child under s 2 of the Children Act 1989 (though this would not constitute 'parent' for the purposes of intestacy rankings which apply to funeral disputes). Significant changes have been introduced elsewhere, which might facilitate a majority rule scenario in equal kinship disputes (if this was the applicable tie-breaker); for example, in Ontario, the All Families Are Equal Act 2016 recognises up to four parents of a child born to a surrogate or where a preconception agreement to parent together was made by up to four people.
} 
deceased's 'adult' children as constituting a potential majority-something which could operate unfairly where one of the deceased's children is a teenager (and, in particular, approaching the legal age of adulthood). It seems inherently wrong, for example, that a 16-year-old's views about their parent's funeral could simply be disregarded. ${ }^{100}$

Where the ranking is based on age, the legal position is clear; if applied, for example, to the opening scenario in this article, the 67-year-old brother would have succeeded over his 66-year-old sister. Despite influencing aspects of succession law, ${ }^{101}$ the use of this particular determinant is inherently problematic when applied to funeral disputes. Age is an arbitrary marker, a mere temporal reference point for separating equal claims. The person who succeeds is legitimised by a convenient rule of law; but, instead of favouring the oldest, ${ }^{102}$ why not impose some other random benchmark such as who's the tallest (even more indiscriminate), or who was quickest in staking their claim by seeking a formal grant of administration over the deceased's estate or claiming the deceased's body (slightly less tenuous, though the outcome could be just as arbitrary). ${ }^{103}$ And while a ranking based on gender would almost certainly be discriminatory, ${ }^{104}$ surely the same applies to seniority? ${ }^{105}$ Yet, there is a counter-argument-at least in the sibling context. Age dictates each person's position and role in the sibling hierarchy; and while birth-order stereotypes should always be treated with caution, first-born children tend to carry more responsibility and assume the role of natural leaders. ${ }^{106}$ Since death literature suggests that traditional family hierarchies re-emerge following the loss of a loved one, ${ }^{107}$ there is a tentative basis for favouring the eldest sibling here. However, the same reasoning breaks down at a number of levels when applied to parental disputes over a dead child. The parent-child bond is unique, with strong and enduring emotional

\footnotetext{
100 The restriction to 'adult' siblings of the deceased in all of the statutes (bar New Jersey) would operate in a similar manner.

101 An obvious example is the commorientes rule in England and Wales: where joint tenants die at the same time and the order of deaths is unclear, the elder is presumed to die first for estate administration purposes under s 184 of the Law of Property Act 1925 (the legal position used to be similar in Scotland, under what was then s 31 of the Succession Law Act 1964). Birth order can also influence perceived entitlements to personal possessions when siblings are dividing these following the death of a parentsee Drake (2007).

102 Or 'older' in the case of two individuals of equal rank. For convenience this discussion uses 'oldest' and corresponding adjectives.

103 For example, applying a 'speed of action' test to Calma v Sesar (1992) 106 FLR 446 (see nn 33-36 and accompanying text) would have resulted in the mother succeeding on the first determinant (grant of administration) and the father on the second (possession of the body).

104 Prioritising a father over a mother might tap into outdated perceptions of family patriarchy, but would constitute gender discrimination (see n 87) - as well as ignoring new variant family forms. See however, Johnson v George [2018] QSC 140 as discussed at nn 66 and 70; although dealing with siblings, the outcome suggests that gender might play a role in specific cultural contexts-though it must be stressed that there were other grounds for the court favouring the brother over his sister.

105 In the employment law context, for example, the Equality Act 2010 makes age discrimination unlawful in the UK.

106 See e.g. Leman (2009) and Emst and Angst (2012).

107 Bowen (1991)
} 
attachments ${ }^{108}$ and, in the absence of family breakdown or estrangement, there is no innate concept of one parent having preferential status. The death of a child also generates much stronger emotions than the loss of a parent or sibling because death is contrary to the natural order of things ${ }^{109}$; and, where disputes occur, the 'normal' grief response tends to be heightened by what was often an acrimonious end to the parents' own relationship. This makes the ranking of parental claims extremely difficult, and not something which should be determined by as arbitrary and emotionally insensitive a marker as age. Finally, a blanket seniority rule takes no account of conduct. For example, an abusive or a violent parent could still dictate their child's funeral arrangements by virtue of being the older parent.

This contrasts sharply with legislative rankings based on lifetime relationships between the deceased and each parent or sibling, of which the Pennsylvania statute is the most radical example. Here the emphasis seems to be on getting the right solution. Emotional closeness has an instinctive appeal, because it recognises and affirms close personal ties; it also acknowledges their fluidity, and that different degrees of attachment can exist within the same familial cohort. The underlying assumption is that the person with the strongest connection to the deceased should be the ultimate arbiter in equal kinship disputes, and that the deceased would want them to be. Outcomes may be difficult to predict, but there is a sense of individualised justice.

At first glance, this particular tie-breaker appears to embrace a family law narrative, reflecting what commentators would view as a 'functional approach' whereby familial relationships are no longer dictated by formal status but by ongoing interactions and assumed responsibilities. ${ }^{110}$ This seems apposite given the subject-matter, but is not entirely true. First, family law seldom assesses the quality of individual relationships, or makes determinations solely on this basis; it prefers a more reflective approach. ${ }^{111}$ Child custody cases are an obvious example: decisions are based on the 'best interests of the child', ${ }^{112}$ and while judges can consider which parent had the closer relationship with the child as part of factual matrix this is one relevant factor-it is not the sole determinant. Secondly, family law tends to be forward looking in terms of addressing future needs and ongoing responsibilities, ${ }^{113}$ as seen in child custody and support obligations as well as property redistribution on divorce. In contrast, deciding who was closest in equal kinship disputes mandates an entirely retrospective inquiry: the court's sole focus is on past relationships between each parent or sibling and the person who is now deceased.

This brings us to the crux of this particular tie-breaker, and what it actually contemplates. The Pennsylvania legislation ignores the interpretative and temporal dimensions of 'closest relationship'-we assume it denotes emotional bonds

\footnotetext{
108 See e.g. Omer et al (2013).

109 Riches and Dawson (1997).

110 See e.g. Glennon (2008) and Atack (2016).

111 For example Bainham (2001) argues that 'backward looking' assessments of fault are increasingly irrelevant in family law disputes.

112 Pursuant to the welfare of the child principle, and welfare checklist, in s 1 of the Children Act 1989 in England and Wales.

113 Lowe and Douglas (2015), ch 1.
} 
and personal interactions, which were ongoing at the time of the deceased's death. In some instances, this might be someone who had a close relationship with the deceased in their final months and weeks; in others, it will have been throughout the deceased's lifetime. Much depends on the shifting sands of family relationships. Case law suggests a range of factors for assessing how close each parent or sibling was to the deceased-for example, the amount of time they spent with the deceased, the frequency of contact, and the provision of care and support, ${ }^{114}$ or the fact that the deceased had entrusted a particular individual with responsibility for their legal affairs. ${ }^{115}$ Of course, one might argue that these factors are not necessarily indicative of an emotionally satisfying relationship; some may simply be about discharging familial duties or geographical proximity if one parent or sibling lived with or nearby the deceased. Yet judicially supplied criteria (in whatever form) are essential here, not just for definitional clarity, but to mitigate the evidential dangers of selfserving testimonies and revisionist family histories from warring parents or siblings. And it is not just about who loved the deceased more, or vice versa.

Deciding who had the 'closest relationship' to the deceased not only raises difficult normative questions; it also requires judges to be sensitive to the affective content of different relationships. The court's function is to evaluate each individual's relationship with the deceased before deciding which tie was the closest or strongest. This is not an easy task, and not just because each individual will regard their own emotional attachment to the deceased as important. Prioritising one parent or sibling on this basis alone requires judges to delve into complex family histories and make subjective value-judgments on personal relations between the living and the dead, something they have been keen to avoid - and not just in equal kinship disputes. As Lord Brodie remarked in C v Advocate General for Scotland ${ }^{116}$ :

Determining what are appropriate funeral arrangements by reference to the quality of relationships within a family appears to me a task for which the court is quite unsuited.

Judicial unease is not a reason, in itself, for rejecting a closest relationship test; nor is the fear of encouraging litigation. The fundamental problem with this particular tie-breaker is the long-term impact of the court's decision. A judgment based on closeness is not an emotionally responsive one for the defeated party or parties. ${ }^{117}$ Individual outcomes in funeral disputes tend to be seen through the binary lenses of winning and losing, but the effect is much more pronounced here: while the victor can reinforce and perpetuate their relationship with the deceased, the emotional consequences are devastating for the parent or sibling(s) who loses because they are

\footnotetext{
114 The symbolic value given to care as part of the meaning of 'family' has been explored elsewheresee e.g. Diduck (2011).

115 Deciding factors in Estate of N.P. 22 Fid. Rep. 2d 473 (Berks Cty. O.C. 2002) and In re Estate of Weiss 2009 Philia. Ct.Com. Pl. LEXIS 236 (Oct. 1, 2009), as well as Keller v Keller [2007] VSC 118 and $A B \vee C D$ [2007] NSWSC 1474.

116 [2011] CSOH 124 at [67].

117 Law and emotion literature stresses the need for emotional intelligence in the family law arena and family contests more generally—see Huntington (2016).
} 
not deemed to have been as close to the deceased. ${ }^{118}$ Even if judges are at pains to stress that they are not saying which person the deceased loved more (or vice versa), decisions will invariably be seen as posthumous and permanent rulings to this effect. This will be hard for the 'losing' party to come to terms with and could trigger a new wave of family resentments.

Judged solely on this basis, a blunt ranking of claims has certain benefits. Both age and majority rule eclipse so much of the underlying situation and say nothing about the protagonists and their respective relationships with the deceased; they are rules of convenience which allow judges to ignore the emotional and contextual backdrops. ${ }^{119}$ However, it is not simply a case of the law abrogating responsibility for making difficult decisions. Such value neutral rulings are undoubtedly more efficient (they require less deliberation than a 'closest relationship' test), and minimise the scope for protracted and bitter disputes between parents or siblings. As McKechnie $\mathrm{J}$ remarked in Ugle $v$ Bowra \& $O^{\prime}$ Dea $^{120}$ :

There has to be a balance between the need for prompt expedition of a matter that involves grief and loss to many people, together with the need to secure burial of a person reasonably promptly, and the need for a full exploration of disputed matters...Pressures of time, stress and pain add to an already emotional situation where there are no winners and losers, only deeply held and legitimate feelings that are exacerbated by uncertainty.

Age or majority preference may be imperfect rules in imperfect settings, but they are quick and dispassionate solutions with damage limitation properties. Warring parents or siblings are prevented from using the courtroom as a forum for replaying old family feuds; and those who lose may find the outcome easier to accept, knowing that it was based on nothing more than a legal rule.

On this basis, age or majority rule might seem preferable to a closest relationship test if choosing between two extremes. Yet, these are not the only options and the following section proposes an alternative statutory matrix for resolving equal kinship disputes, which draws on the more nuanced schemes in Minnesota and the District of Columbia, and could be implemented elsewhere.

\footnotetext{
118 When presenting this paper at an event, one participant said that, if she and her siblings disagreed about their parents' funeral arrangements, she could cope with losing because she was not the oldest child-but not if she wasn't the closest child.

119 And while the dead should be treated with respect, some might argue that courts should concentrate on the living instead of devoting their time to contested corpses or ashes. However, such a rationalist stance overlooks the fact that most funeral disputes occur immediately after death when the deceased is biologically dead but still very much 'alive' in a familial sense-as Lord Brodie remarked in $C v$ Advocate General for Scotland [2011] CSOH 124 at [39], because "someone has died does not mean that he is no longer regarded as part of the family". The final decision will also have a major impact on everyone involved as they struggle to come to terms with the loss of a loved one, and the emotional fallout from the litigation.
}

${ }^{120}$ [2007] WASC 82 at [1]. 


\section{A Customised Alternative}

If legislating for equal kinship disputes, both England and Wales and Australia are obvious candidates. ${ }^{121}$ The prevailing common law narrative allows for flexibility, but makes for uncertainty as judges are forced to adjudicate on a case-by-case basis with little legal guidance. Inconsistent outcomes, alongside other seemingly pertinent factors being overlooked or downgraded in individual cases, ${ }^{122}$ also strengthen the argument for a discrete set of guiding principles to assist judges and bring muchneeded clarity to the area.

The starting point in all equal kinship disputes (and in funeral disputes generally) should be the deceased's own funeral instructions. This is already the position in British Columbia and in each of the four US states discussed here ${ }^{123}$; other jurisdictions are contemplating a similar shift in the law, ${ }^{124}$ while a number of recent English cases are placing greater emphasis on what the deceased wanted. ${ }^{125}$ Whether the expressed wishes of the dead should be paramount, raises issues beyond the scope of this paper. However, the fact that many people assume they can decide what happens to their mortal remains suggests some sort of normative preference for upholding funeral instructions, while the core values of autonomy and self-determination also come into play: what we are doing here is respecting ante-mortem choices which take effect on death. ${ }^{126}$ Prioritising the deceased's wishes in equal kinship disputes not only reflects this; it give judges a clear focal point (they simply select the parent or sibling intent on carrying out these wishes), and moves the emphasis from the warring parties to the person whose corpse or ashes is being contested (similar to the child welfare test in custody disputes). ${ }^{127}$ Of course, an obvious danger is that the locus of the dispute shifts to what the deceased's wishes actually were, though this could be countered by insisting on written preferences (for example, in a will, pre-paid funeral plan, or personal correspondence such as email exchanges) or clear and verifiable oral statements to this effect. ${ }^{128}$ However, default rules will still be

\footnotetext{
121 As are the other jurisdictions mentioned in $\mathrm{n} 30$. And despite the changes contemplated by the Burial and Cremation (Scotland) Act 2016, the statute has no specific rules for dealing with equal kinship disputes.

122 As highlighted in the section entitled 'Pragmatism Over Principle' above.

123 And in the US more generally-see n 81. In Scotland, s 65 of the Burial and Cremation (Scotland) Act 2016 will allow individuals to make an "arrangements on death declaration" (effectively nominating a person to carry out their funeral arrangements); this can be upheld by courts, giving some credence to funeral preferences.

124 Most notably New Zealand (New Zealand Law Commission (2015), Pt 4) and the Australian state of Victoria (see Victorian Law Reform Commission (2016)).

125 See Burrows v HM Coroner for Preston [2008] EWHC 1387 (Admin) for a strong endorsement, as well as Anstey v Mundle [2016] EWHC 1073 (Ch) and Re JS (Disposal of Body) [2016] EWHC 2859 (Fam). From an Australian perspective, see the respective comments in Ugle v Bowra \& O'Dea [2007] WASC 82 and State of South Australia v Smith [2014] SASC 64.

126 See Conway (2016), ch 5 as well as Nwabueze (2013) and Sperling (2008), ch 4.

127 See e.g. Smart and May (2004)_illegitimate' issues such as parental blame and recriminations are eclipsed by the 'welfare of children' emphasis in the Children Act 1989.

128 Each parent or sibling might claim that the deceased told them something different, as in the Northern Ireland dispute mentioned in the opening paragraph, and Anstey v Mundle [2016] EWHC 1073 (Ch).
} 
needed in two situations: where the dispute involves a dead infant or minor, ${ }^{129}$ or in adult deaths where the deceased's own preferences are unspecified or unclear.

But what factors should apply here? The deceased's religious or cultural beliefsinsofar as these might influence the choice of funeral arrangements-would seem to be an obvious one, as would the deceased's emotional, spiritual or geographical ties to a particular place (in disputes over where to inter the body or scatter the ashes). Again the legislative focus would be on the deceased's own values and attachments, not those of the warring siblings or parents. From a more objective stance, the practicalities surrounding the proposed funeral arrangements are important: these exert a huge influence at common law, and are also reflected in the statutory checklists for separating equal kinship claims in both Minnesota and the District of Columbia. The same statutes also include the degree of personal relationship between the deceased and each parent or sibling; while open to criticism as a sole determinant, this might be relevant as part of a broader contextual inquiry but with additional safeguards to capture negative conduct. For example, courts could look at any enduring estrangement between the deceased and a particular party, as well as past allegations of violent or abusive conduct (physical or emotional). ${ }^{130}$ And while the sheer arbitrariness of an age-based marker makes it unsuitable, majority preference between feuding siblings could be a useful addition to the legislative checklist—as opposed to being the sole determinant. However, this should not be confined to adult siblings; when disputes arise over the funeral arrangements for a dead parent (or, to a lesser extent, dead siblings) there should be scope for taking the views of younger children into account where they have strong opinions on the matter. Lowering the age to 16 would not be controversial, ${ }^{131}$ and there may even be an argument for allowing input from teenagers - those aged 13 or more could be part of the collective for majority rule purposes. ${ }^{132}$ Finally, where separated parents are fighting over dead infants or minors, courts could also consider what custody or residence arrangements were in place for the child, and why.

These factors would not have any specific weighting, though some might be more influential than others in the context of a particular case; and they would only come into play if the deceased's own funeral instructions failed to resolve the issue. What is being proposed here is a specialised and facilitative legal solution which is still sufficiently adaptable to deal with diverse factual scenarios. A specific frame of reference would make the law more accessible for feuding parents and siblings, while

\footnotetext{
129 Since most children (and many young adults) may not have articulated or even contemplated their own funeral preferences, though isolated examples exist-see Burrows v HM Coroner for Preston [2008] EWHC 1387 (Admin) (teenage boy who committed suicide had wanted to be cremated) and Re JS (Disposal of Body) [2016] EWHC 2859 (Fam) (dying teenager wanted to be cryogenically frozen).

${ }^{130}$ Drawing on the Pennsylvania model-see $n 89$.

131 Various statutes give decision-making capacity to those aged 16 or over, including s 8 of the Family Law Reform Act 1969 which deals with consent to medical or dental treatment. The English Law Commission is also considering whether to lower the age of testamentary capacity from 18 to 16-Law Commission (2017), ch 8 .

132 This chimes with child custody disputes in which the views of children (especially older children) can be taken into account (in England and Wales, see s 1(3)(a) of the Children Act 1989), and is part of a wider trend in family law—see Parkinson and Cashmore (2009).
} 
allowing effective participation in the legal process (something which does not occur when the outcome is dictated solely by age). Judges would still have to assimilate the facts and devise an appropriate legal response, but would have clear legislative guidance-allowing them to reach conclusions expediently, and without getting drawn into complex family histories. And, where the default ranking is triggered, a bounded set of factors not only limits the judicial zone of inquiry; it prevents both sides from raising extraneous issues, and might de-escalate the conflict or at least prevent it from spiralling out of control.

This customised statutory alternative may not remove the incentive to litigate (something which seems endemic here) or make the final outcome any more predictable in equal kinship disputes (assuming the deceased's own funeral instructions failed to settled the matter). However, there would be a more coherent, streamlined and reflective basis for decision-making than the current common law approach or some of the statutory alternatives analysed here.

\section{Conclusion}

Family funeral disputes are as sad and inevitable as the deaths which trigger them. Set against a backdrop of time constraints and intra-familial turmoil they stir up intense feelings of bitterness and acrimony as the emotional ante of the conflict is upped by the raw, consuming emotions of death. ${ }^{133}$ In some respects, funeral disputes are non-justiciable; aside from the inevitable time and expense, they inflict a heavy toll on everyone involved (the human cost far outweighs the economic), and judges dislike conflicts which delay the disposal of the dead and cannot always be settled by discrete legal principles. The final observation is particularly apt where the protagonists have equal rights but different views, and the competing interests are often finely balanced on each side.

Equal kinship disputes are highly individualistic yet, at the same time, intrinsically relational: at their core is each person's connection to the deceased versus their own difficult relationships with each other. In many of these cases, the legal contest will have its genesis in issues which are unrelated to the seemingly narrow issue of funeral arrangements. Feelings and emotions run high as old family grievances and latent resentments are aired through the refractive prism of grief. Given the context and sensitivity of the conflict, those involved should be encouraged to reach a consensus. However, this is not always possible as arguments and intransigence dominate.

Legal intervention becomes inevitable, yet the law also confronts its own limitations here; there is no legal solution that will adequately meet the emotional needs of everyone involved because each person will have deeply held and extremely personal views on the matter, and the damage inflicted on the warring parents or siblings means that the end result will always be something of a Pyrrhic victory. What is needed is the best possible legal mechanism to solve the insoluble, and the

133 Conway and Stannard (2011). 
customised statutory framework suggested here might just achieve that. It still contemplates an evaluative response, in the sense of choosing one parent or sibling over the other(s). Yet, by focusing on the deceased's own funeral preferences to begin with, there is a clear mandate for the court's decision, embracing what has been termed the "modern autonomy trajectory". ${ }^{134}$ Failing that, a collective checklist of evaluative criteria ensures a multifaceted approach to decision-making but within set parameters. These create a containment zone for the conflict-something which is in the best interests of everyone involved.

Acknowledgements Thanks to my colleagues, Professors Anne-Marie McAlinden and Kieran McEvoy, and to Dr Sharon Thompson, Cardiff Law School, for their insights on an earlier draft.

\section{Compliance with ethical standards}

Conflict of interest The author verifies that there is no conflict of interest in this research.

Open Access This article is distributed under the terms of the Creative Commons Attribution 4.0 International License (http://creativecommons.org/licenses/by/4.0/), which permits unrestricted use, distribution, and reproduction in any medium, provided you give appropriate credit to the original author(s) and the source, provide a link to the Creative Commons license, and indicate if changes were made.

\section{References}

Altman, Irwin, and Setha M. Low. 1992. Place attachment. New York: Plenum Press.

Atack, Meghan. 2016. Traditional and functional views of the family in the law. North East Law Review 4(1): 56-61.

Bainham, Andrew. 2001. Men and women behaving badly: Is fault dead in English family law? Oxford Journal of Legal Studies 21(2): 219-238.

Bowen, Murray. 1991. Family reaction to death. In Living beyond loss: Death in the family, ed. F. Walsh, and M. McGoldrick, 47-60. New York: WW Norton and Co.

Conway, Heather. 2016. The Law and the Dead. Abingdon: Routledge.

Conway, Heather, and John Stannard. 2011. The honours of Hades: Death, emotion and the law of burial disputes. University of New South Wales Law Journal 34(3): 860-897.

Diduck, Alison. 2011. What is family law for? Current Legal Problems 64(1): 287-314.

Drake, Deirdre. 2007. The will: Inheritance distribution and feuding families. In Remembering me: Constructing immortality: Beliefs on immortality, life and dead, ed. M. Mitchell, 89-102. Abingdon: Routledge.

Emst, Cecile, and Jules Angst. 2012. Birth order: Its influence on personality. New York: Springer.

Freckelton, Ian. 2009. Disputed family claims to bury or cremate the dead. Journal of Law and Medicine 17(2): 178-183.

Glennon, Lisa. 2008. Obligations between adult partners: Moving from form to function. International Journal of Law, Policy and the Family 22(1): 22-60.

Hamzelou, Jessica. 2016. World's first baby born with new '3 parent' technique. The New Scientist, 27 September 2016.

Hernandez, Tanya. 1998. The property of death. University of Pittsburgh Law Review 60(4): 971-1028.

Huntington, Clare. 2016. Affective family law. In The emotional dynamics of law and legal discourse, ed. H. Conway, and J. Stannard, 9-33. Oxford: Hart Publishing.

134 Hernandez (1998), p 1022. 
Josias, Brian L. 2004. Burying the hatchet in burial disputes: Applying alternative dispute resolution techniques to disputes concerning the interment of bodies. Notre Dame Law Review 79(3): 1141-1181.

Law Commission. 2017. Making a Will. Consultation Paper 231.

Leman, Kevin. 2009. The birth order book. Elk Grove Village: Revell.

Lowe, Nigel, and Gillian Douglas. 2015. Bromley's family law. 11th ed. Oxford: Oxford University Press.

Milevsky, Avidan. 2013. Till death (of our parents) do us part. Psychology Today, 6 June 2013. https ://www.psychology today.com/blog/band-brothers-and-sisters/201306/till-death-our-paren ts-do-us-part.

New Zealand Law Commission. 2015. Death, burial and cremation: a new law for contemporary New Zealand. Report 134.

Nwabueze, Remigius N. 2013. Legal control of burial rights. Cambridge Journal of International and Comparative Law 2(2): 196-226.

Oldfield, Yvonne. 2014. Disputes over interment and cremation: The mediation option. Victoria University of Wellington Law Review 45(4): 613-636.

Omer, Haim, Sarit G. Steinmetz, Tal Carthy, and Arist von Schlippe. 2013. The anchoring function: Parental authority and the parent-child bond. Family Process 52(2): 193-206.

Parkinson, Patrick, and Judy Cashmore. 2009. The voice of a child in family law disputes. Oxford: Oxford University Press.

Petersson, Anna. 2010. The production of a memorial place: Materialising expressions of grief. In Deathscapes: Spaces for Death, Dying, Mourning and Remembrance, ed. A. Maddrell, and J.D. Sidaway, 141-160. Abingdon: Routledge.

Riches, Gordon, and Pamela Dawson. 1997. 'Shoring up the walls of heartache': Parental responses to the death of a child. In Death, gender and ethnicity, ed. D. Field, J. Hockey, and N. Small, 52-75. London: Routledge.

Sperling, Daniel. 2008. Posthumous interests: Legal and ethical perspectives. Cambridge: Cambridge University Press.

Smart, Carol, and Vanessa May. 2004. Why can't they agree: The underlying complexity of contact and residence disputes. Journal of Social Welfare and Family Law 26(4): 347-360.

Victorian Law Reform Commission. 2016. Funeral and burial instructions: Report. 